DOI: 10.20472/IAC.2018.043.012

JOHAN HATTINGH

Central University of Technology, Free State, South Africa

\title{
LOCAL ECONOMIC TOURISM DEVELOPMENT: LESSONS FROM SOUTHERN AFRICA
}

\begin{abstract}
:
As one of the largest industries in the world, the tourism industry has a positive economic impact on countries. This is especially true for developing countries where tourism is an essential driver for economic growth and development. In this regard Africa and specifically Southern Africa has plenty to offer tourists. The Southern African Development Community (SADC) is a regional economic community comprising fifteen member states, namely Angola, Botswana, Democratic Republic of Congo, Lesotho, Madagascar, Malawi, Mauritius, Mozambique, Namibia, Seychelles, South Africa, Swaziland, Tanzania, Zambia and Zimbabwe (SADC, 2017). The tourism industry in the SADC region has been growing rapidly and the region has prioritized tourism as a means of promoting economic development and regional integration (SADC, 2017). For the fulfillment of these goals, a protocol on the development of tourism was created. The protocol aims to use tourism as a means for sustainable development drawing on the region's natural and cultural resources (SADC, 2017).

Southern Africa has large rural areas and many communities in need of local economic development (LED). LED is thus an on-going concern. Route tourism is often seen as a means to attract tourists to rural areas and to ensure that product owners, community members and governments are involved in a coordinated way (World Bank, 2017). The paper intends to reflect on the local economic development activities of two areas in Southern Africa where local economic development tourism has been contemplated. This includes the Maloti Drakensberg Tourism Route in South Africa and the Four Deserts Tourism Route in southern Namibia. The aim of the paper is to contribute theoretically and empirically to the development of approaches that enable growth for rural areas and to identify how LED has been implemented or not in the two study areas. Although the paper reflects a southern African perspective it will provide valuable insights applicable to other local economic tourism initiatives.
\end{abstract}

\section{Keywords:}

Sustainable tourism development,local economic development, Southern Africa, Maloti Drakensberg Route, Four Deserts Tourism Route, South Africa, Namibia.

JEL Classification: L83 


\section{Introduction}

Africa has some of the fastest-growing economies in the world and the tourism sector plays a pivotal role in the economic development of these and other emerging countries. According to Spenceley and Meyer (2012) some of the poorest regions in the world have rich cultural and natural assets that can attract tourists. As tourists travel to less developed regions, they spend money on travel, accommodation, excursions, food, drinks and shopping. This creates opportunities for communities to generate income by offering goods and services (National Department of Tourism: NDT 2017 Revised Draft of the National Tourism Sector Strategy 2020 NTSS; Page, \& Connell, 2014; Keyser, 2011).

The tourism industry is strategically seen as one of the core areas in ensuring economic growth and sustainability in Africa (Ncube M, Nyarko Y and Bergman E, 2013). For the sustainable use of tourism, effective planning is necessary to ensure that Africa's existing natural resources (such as natural beauty and rich cultural heritage) are managed sustainably.

Africa is considered the world's youngest continent with close to $70 \%$ of its population aged below 25 . However, the youth constitutes about $60 \%$ of the total unemployment rate. Investment in education and training can be beneficial to the continent if new skills enable job creation (Ncube et al., 2013:9). According to Christie, Fernandes, Messerli and Ward (2013:17), the tourism industry in Africa can be a powerful development path because it can promote the inclusive growth of the rural populations especially. Tourism in Western Africa contributed 5.6\% to GDP. Tourism in Southern Africa contributed 8\% to GDP. The lowest contribution of tourism to the GDP was registered in Central Africa, accounting for only $1 \%$ of GDP (World Bank, 2017).

According to the World Bank's Development Indicators, tourism is an important economic activity in $70 \%$ of developing countries. In 28 of the 49 Sub-Saharan African countries, tourism contributes more than $3 \%$ of gross domestic product (GDP). The potential to utilise tourism as a tool for sustained socio-economic development is thus justified (World Bank, 2017; Lourens, 2007).

This study identified two Southern African Development Community (SADC) countries namely South Africa and Namibia with relevant local economic development programmes in the tourism sector. According to the SADC (2018) "The main objectives of the SADC are to achieve development, peace and security, and economic growth, to alleviate poverty, enhance the standard and quality of life of the peoples of Southern Africa, and support the socially disadvantaged through regional integration, built on democratic principles and equitable and sustainable development". 


\section{Literature Review}

\subsection{The Southern African Development Community (SADC)}

The SADC is a regional economic community comprising fifteen member states, namely Angola, Botswana, Democratic Republic of Congo. Lesotho, Madagascar, Malawi, Mauritius, Mozambique, Namibia, Seychelles, South Africa, Eswatini (Swaziland), Tanzania, Zambia and Zimbabwe (SADC, 2018). The SADC was established in 1992 with the purposes of regional integration and poverty eradication within Southern Africa by means of economic development and assuring peace and security. The executive secretariat is located in Gaborone, Botswana and is responsible for strategic planning and management of all programmes (SADC, 2018). Areas of concern include trade, industry, finance and investment, infrastructure and services, agriculture and natural resources, social and human development, and policy planning and resource mobilisation (SADC, 2018).

The tourism industry in the SADC region has been growing rapidly. The region has prioritised tourism as a means of promoting their goals of economic development and regional integration (SADC, 2018). For the fulfilment of these goals, a protocol on the development of tourism was created. This protocol aims to use tourism as a means for sustainable development drawing on the region's natural and cultural resources (SADC, 2018).

The tourism sector in the SADC region creates numerous employment opportunities and attracts capital investment (World Travel and Tourism Council WTTC, 2018; Akama \& Kieti, 2007:735). The tourism sector has contributed 4819500 job opportunities in the SADC region during 2014 with an estimated increase of $2.2 \%$ or 6 000000 jobs that are expected to be created by 2022 (WTTC, 2018). In 2011, the SADC region has generated US $\$ 18.1$ billion in tourism exports. This is expected to increase to US $\$ 30.8$ billion by 2022 (WTTC, 2018). The tourism sector has attracted capital investment of around US $\$ 8.5$ billion to SADC countries in 2011. This contribution is expected to increase by $3.7 \%$ annually and to reach US $\$ 12.5$ billion in 2022 (WTTC, 2018).

This study investigates the role of local economic development in the following two Southern African SADC member countries: South Africa and Namibia. The areas are indicated in Figure 1 below. 


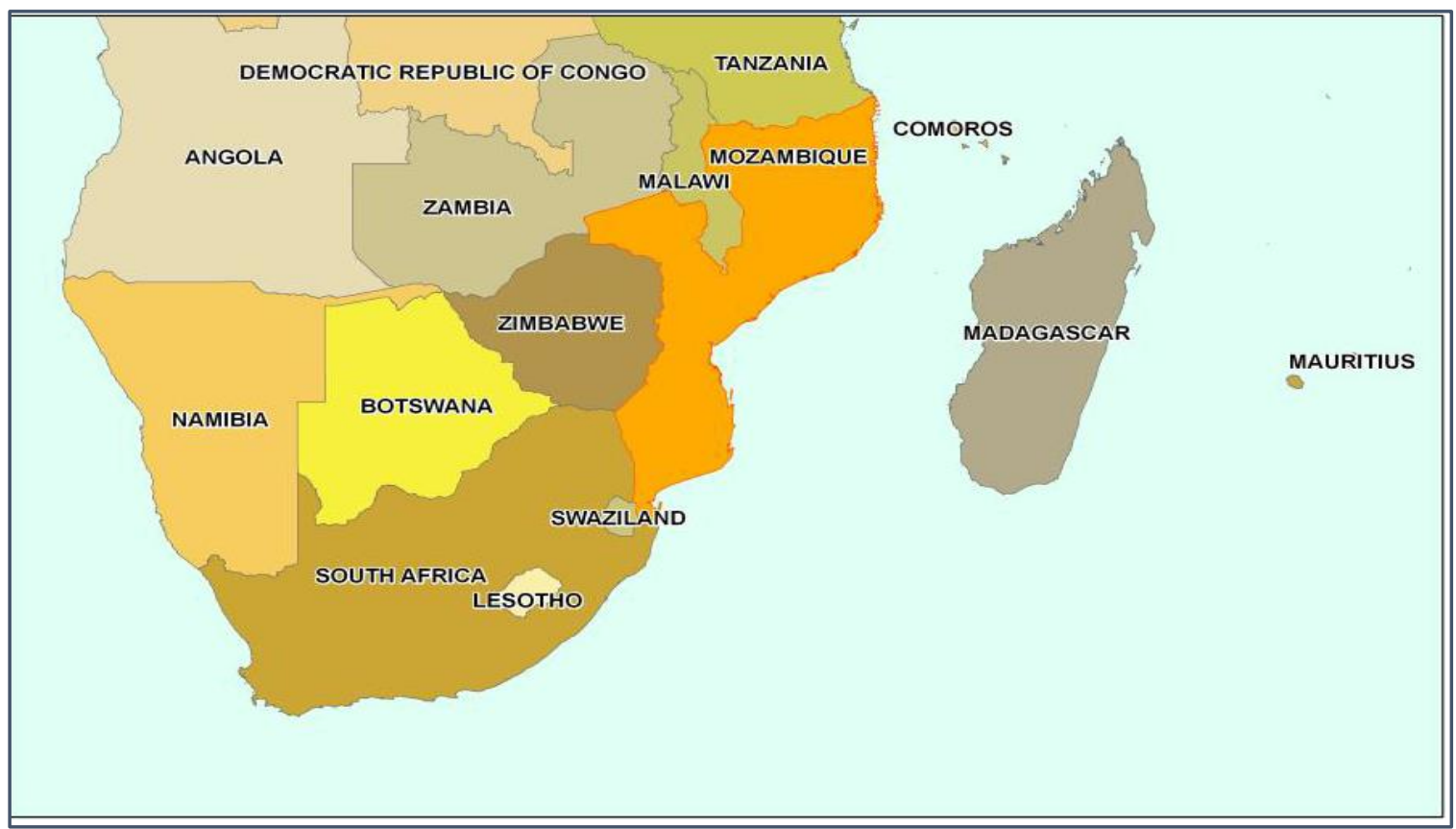

Figure 1: South Africa and Namibia: Maps of Southern Africa (2018: Online)

The next section will profile the tourism landscapes of South Africa and Namibia.

\subsection{South Africa}

South Africa welcomed 10.29 million foreign tourists (visitors who stayed overnight) in 2017. This is up only $2 \%$ over 2016 . Tourism in South Africa has been targeted as one of the key sectorial drivers for economic development and transformation (NTSS, 2017; Rogerson, 2004). The WTTC indicated that travel and tourism in South Africa directly and indirectly employ more people than the mining, communication services, automotive manufacturing and chemical manufacturing sectors, whilst the South African tourism sector boasts a phenomenal diverse tourism resource base. This range from natural attractions (such as unspoilt beaches, wildlife, mountains, lakes and rivers) to man-made attractions (such as Sun City, Kimberley big hole, and San rock art (South Africa Tourism (SAT), 2018). Bunghez, (2016) and Swarbrooke (1999) argues that attractions are the most important component in the tourism system as they are the core of the tourism product and motivators for tourist trips.

In its bid to grow the current domestic South African tourism market and influence South Africans to travel more within the country, the Domestic Tourism Growth Strategy 20122020 was launched in 2012 which aims to grow domestic tourism for a sustainable tourism economy. This was as a follow up on the success of the 'Sho't Left' marketing campaign that was launched in 2004. The 'Sho't Left' marketing campaign focused on the youth whilst the new strategy is underpinned by event promotion and packaging, for example, sports, music, lifestyle, cultural events across the country (Domestic Tourism Growth Strategy, 2012). SAT (2018) maintains that it's 'Sho't Left' marketing campaign 
for domestic tourists has delivered positive results as was reflected by an increase of domestic tourists.

The new policy frameworks that were put in place post the apartheid era were key foundations in the further development of South African tourism. These included the National Tourism Sector Strategy of 2011, revised in 2017 and the South Africa tourismplanning toolkit for local Government in 2009. In order to fulfil the strategic gap of inadequate capacity, the NTSS envisage a sector-driven turnaround strategy between CATHSSETA and the Department of Higher Education and Training (DHET) (NTSS, 2017).

The re-address of inequalities brought about by the apartheid government (1948-1994) resulted in the South African government focussing on empowering the previous economically disadvantaged communities though the Black Economic Empowerment (BEE) strategy. The BEE strategy is aimed at increasing black participation at all levels in the country by re-addressing the imbalances of the past. Stakeholders had to forge strong alliances with national and provincial partners. Examples include South Africa Tourism's partnership with more than 50 tourism companies to create discount vouchers (ranging from tour-operator services, accommodation and experiences) and the "It's Here, Vaya Mzansi" campaign. The campaigns rely on collaboration and partnership with the tourism industry stakeholders, for their success (SAT, 2018). Furthermore, the successful partnerships with stakeholders (provinces and municipalities) have improved brand awareness and enhanced growth in foreign tourist arrivals (Xasa, 2016).

\subsection{Namibia}

In Namibia tourism has grown rapidly since the country gained independence from South Africa in 1990. It is a major industry, directly contributing to the country's Gross Domestic Product (GDP) and employment creation. The foreign tourist arrivals for Namibia in 2016 have increased by 3\% from 2015. Nearly one million travellers visit Namibia annually, with about one in three coming from South Africa, followed by Germany, the United Kingdom, Italy and France. Namibia is among the prime destinations in Africa and is known for eco-tourism which features Namibia's extensive wildlife heritage. Overall about $27 \%$ of all employment in the country is generated through travel and tourism (Ministry of Environment and Tourism (MET) Namibia, 2016).

Namibia is situated in the South Western corner of Africa and borders to the west on the Atlantic Ocean. It shares borders with Angola and Zambia in the north, Botswana in the east and South Africa in the south and east. Namibia is a semi-arid country with very hot summers and cold winters. Its climatic conditions differ in the north from warm humid conditions with high rainfall figures to cold winter months and hot summers whilst dry conditions and lower rainfall figures are prevalent in the south. The first and oldest inhabitants of the area were the San, believed to have lived here for more than 
30000 years. Other groups include the Khoikhoi, Damara and Namaqua (Turpie J, Lange G, Martin R, Davies R, and Barnes J, 2004; Scholz 2009).

Namibia derive its name from the Namib Desert, which is named after the Nama word Namib, meaning open space and is thus known as the "land of open spaces". Namibia has one of the lowest populations in the world with less than two people per $\mathrm{km}^{2}$. Namibia is a member state of the United Nations (UN), the Southern African Development Community (SADC), the African Union (AU), and the Commonwealth of Nations. Namibia's natural and cultural assets provided a substantially good base for tourist attractions, which are scattered across the country and therefore could spread the development impact to different areas. Internationally the tourism market, in Namibia was perceived as a new and unexplored destination (Turpie et al. 2004; Scholz 2009).

Therefore, new tourism ventures and foreign investments in tourism started to flourish. In addition, Namibia offers diverse historical attractions through its heritage tourism which is considered underdeveloped. The heritage and cultural assets include ancient rock art and the pastoralist cultures of the Ovahimba and San people of the Kunene region and the Kalahari Desert respectively which are promoted as tourist attractions. Other historical and cultural attractions are linked to the country's German colonial legacy and are found mostly in Windhoek and coastal towns of Luderitz, Walvis Bay and Swakopmund (Turpie et al. 2004; Scholz 2009:156).

The mainstay of tourism is about $70 \%$ nature-based tourism and $40 \%$ of Namibia is under some form of natural protected area, communal conservancies (16\%), freehold conservancies and private reserves $(6 \%)$ and community forests $(0.8 \%)$. The tourist arrivals to Namibia for the period of 2010-2015 show a slight growth of $5.1 \%$ in the tourist arrivals as compared to 2014. Compared to a 12.2\% increase in arrivals of 2014 as compared to 2013, in 2015 growth was minimal. The tourist arrivals by purpose of visit, revealed that the majority of tourists visit Friends/Relatives as shown by the $53 \%$ share, whereas those visiting Namibia for Holiday purposes as proven by the $77 \%, 71 \%$ and $58 \%$ respectively. The South African tourist market are the highest to Namibia in the top ten holiday list, with $29.7 \%$, followed by the Angolan tourists of $28.7 \%$, Germany ranks third with $16.1 \%$ and the Netherlands the least with $2.5 \%$. International tourists uses air travelling, while many tourists from Africa tend to use road transportation when visiting Namibia. (Report on the Namibia Tourism Exit Survey 2012-2013, 2013; Namibia Tourism Satellite account, 5th ed. n.d.).

\subsection{Local Economic Development (LED)}

The World Bank (2018) defines LED as the process by which public, business and nongovernmental sector partners work collectively to create better conditions for economic growth and employment generation. The purpose of LED is to build up the economic capacity of local areas to improve its economic future and create a quality of life for all. 
Nel and Humphrys (1999) describe LED as the process by which locally based individuals or organisations use resources to modify or expand local economic activity to the benefit of the majority in the local community.

LED is essentially a process in which local government and/or community-based groups manage their existing resources and enter into partnership arrangements with the private sector, or with each other, to create new jobs and stimulate economic activity in an economic area. Although these definitions emphasise different aspects, it is evident that the core focus of LED is on partnerships, economic sustainability, job creation and the improvement of quality of life and infrastructure within the context of communities or at local level. In the South African context, LED refers to actions initiated at the local level, typically by a combination of partners, to address particular socio-economic problems or respond to economic opportunities (South African Tourism Planning Toolkit, 2010).

The goal of LED is to create a conducive environment for business development, enhancing local skills and engaging various stakeholders for planning and implementation (Rogerson and Nel, 2016). Africa, due to its uniqueness regarding its diversity of cultures, has been experiencing difficulties in implementing LED policies developed for other parts of the world (Reddy and Wallis, 2012). However, South Africa is regarded as an anomaly because of some degree of success being achieved in LED (Rogerson and Nel, 2016).

Local and regional governments generally face constraints such as a lack of funding and government capacity with regard to skills and infrastructure which hamper the development and implementation of successful strategies. Most research on African LED activities centres on South Africa because LED is legislated as a reform mandate for local governments LED practice and research in the South African context has become a laboratory, and many aspects have been exported to other African countries (Rodríguez-Pose \& Tijmstra, 2007).

Rogerson and Visser (2004), argues that the most important policy documents were the White Paper on Development and Promotion of Tourism in South Africa (DEAT 1996), and the White paper on Local Government of 1998 (DEAT 1998). The vision set out in the white paper was to develop the tourism sector as a national priority in a sustainable and acceptable manner, so that it would contribute significantly to the improvement of the quality of life of every South African.

The White Paper on the Local Government Republic of South Africa, (1998) also advocates that "Local Government should be committed to working with citizens and groups within the community to find sustainable ways to meet their social, economic and material needs and improve the quality of their lives" (DEAT,1998). The White Paper directly states that LED should be a developmental outcome of municipalities, as they can play an essential role in advancing the creation of jobs and boost the local 
economy. Therefore, municipalities must first invest in the basics, such as providing good-quality cost-effective services and by making the local area a pleasant place to live and work. In terms of the White Paper, municipalities were given the responsibility toward the people within their area of jurisdiction and therefore they are accountable for all actions (DEAT, 1998).

In Namibia, LED is still in its infant stages; however, the country adopted the White Paper on LED in 2009, supported by the GTZ (German Technical Cooperation). GTZ is also behind the Local Economic Development Agency (LEDA) being set up within the Ministry to support municipalities in developing LED strategies and processes going forward. The vision for LED in the White Paper on LED in Namibia acknowledges that national efforts are geared to enhance the conditions for greater global competitiveness in the country (GTZ, 2008).

The White Paper further asserts that it is at the local and regional level that opportunities are identified through the active involvement of local people and the responsiveness of public and private actors. It does not prescribe any specific action to local players but aims to create a common understanding of regional and local economic development as a concept, and provide practical examples of initiatives which are drawn from local and international LED practices. The White Paper then provides a framework for local and regional development, and adds value to national development initiatives without being prescriptive (GTZ, 2008).

\section{Methodology}

The research approach for this study was quantitative. Quantitative research is the systematic investigation of observable phenomena by means of statistical, mathematical or numerical data or computational techniques (Zigmund, 2003; Cooper \& Schindler, 2006; Parasuraman, Grewal \& Krishnan, 2007; Malhotra, 2010; George, 2014). Quantitative research generates a reliable and valid amount of data on the subject being studied from a large number of representative samples (Finn, Elliot \& Walton, 2000; Malhotra \& Birks, 2003; Aaker, Kumar \& Day, 2007; Elliott \& Percy, 2007; Maree \& Pietersen, 2007; Struwig \& Stead, 2007).

Research design is the conceptual structure within which the research is conducted. Research design is a plan of action prepared by the researcher for the collection, measurement and analysis of data to address the research problem (Mustafa, 2010; Carroll, 2015). According to Kumar (2008), a research design is a detailed plan adopted by the researcher to obtain answers to research questions. The research design for this study was survey research, and a semi-structured questionnaire was administered to participants in the two countries. Survey research is a method used for collecting information by asking questions 
The South African study targeted the Free State Provincial part of the Maloti Drakensberg Tourism Route (MDTR). As this is the longest tourism route in South Africa, stretches all around Lesotho and incorporates the Eastern Cape, KwaZulu-Natal and Free State Provinces, the study concentrated on one provincial part of the route only. This study also incorporated a quantitative research design.

The research data was gathered by means of two structured questionnaires that were administered to product owners on the route and tourists who were visiting the route during the research period. The reason behind using the two research questionnaires were to ensure that both the visitors experience of the MDTR, as well as the product owners experience of the MDTR can be clearly interpreted. The development of the questionnaires was based on the research of Lourens (2007) and Meyer (2004).

Data collection was personally administered by the researcher whom travelled to all the product owners that form part of the scope of the study. Appointments were made with product owners beforehand to obtain their consent. Tourists that visited the sites of product owners on the day of the researcher's visit were approached for data collection. Data was collected from tourists by the researcher's research assistant, which was personally trained by the researcher himself beforehand. Tourists were approached and their consent was asked to complete the questionnaires.

The population of this investigation was the product owners and tourists on the Free State Province section of the MDTR. There were 51 members that form part of the MDTR on the Free State Province section of the route that formed part of the study. The entire population was thus utilized. This included restaurants, accommodation establishments and adventure companies. As there were no statistics available on the number of tourists that visit the route, convenience sampling applies to the tourists. Convenience sampling (also known as accidental sampling) makes no pretence of identifying a representative subset of a population. It takes people or other units that are readily available-for instance, those that arrive on the scene by mere happenstance (Leedy \& Ormrod 2010). Tourists visiting the various establishments during the time of data collection on the MDTR were requested to complete a questionnaire.

The Namibian research focussed on the Four Deserts Tourism Route, a tourism route in the southern part of Namibia. The research design applicable to this study was survey research as respondents were requested to complete semi-structured questionnaires. A single questionnaire was administered to the relative participants, tourism product owners and LED officers, on the Four Deserts Tourism Route. For the sake of the investigation on the Four Deserts Tourism Route, the entire population of product owners (including owners of accommodation establishments, arts and craft shops, activity operators, etc.) and LED officers (government officials from the Ministry of Environment and Tourism) within the different towns on the Four Deserts Tourism Route was included. A total of 250 product owners and government officials were targeted, of which only 177 completed the questionnaires. This represents a response rate of $62 \%$. 


\section{Lessons from South Africa}

The Maloti Drakensberg tourism route, although not the most well known in South Africa, is the longest and one of the oldest routes in the country. The study focused on the Free State province side of the route and research were aimed at tourist product owners and tourists on the route itself during data collection.

Tourist product owners on the route mainly consisted of accommodation providers, restaurants and arts and crafts shops. Unlike the Four Deserts route in Namibia, the MDR route does have an official route managing organisation known as the Maloti Drakensberg Tourist Route Forum (MDTRF). This forum is responsible for tourism development, marketing and LED activities. The research findings indicated that most $(56 \%)$ of the product owners, had no interaction with the MDTRF for a period of two years. The also indicated poor communication as well as lack of managerial and marketing assistance from the MDTRF. This in itself poses problems as a lack of communication hinders LED as tourism role players are not kept up to date with tourism developments in their area of operations. Product owners further indicated that tourist information services as well as good quality infrastructure were lacking. Out of date and lack of relevant signage also featured as one of the main hindrances for successful LED growth. The product owners reiterated that they receive little support from the MDTF with regards to marketing. This incorporates the views of Meyer (2004) that a successful route benefits the product owners by exposing tourists to lesser known attractions and rural areas, which would ultimately benefit LED development.

Recommendations that address LED and management effectiveness of the Free State section of the MDTR.

5. The MDTRF must create a robust marketing strategy. This must include the following aspects: a) More marketing material needs to be made available and updated regularly. b) The map of the Free State section of the MDR needs to be updated regularly. c) The MDTRF should have stalls at trade shows such as the Tourism Indaba in Durban.

6. Communication with product owners needs to be better coordinated. This can be done through monthly newsletters, creating WhatsApp groups and the like.

7. An annual meeting or conference can also assist members in knowing each other's challenges and in opening up communication channels with the MDTRF.

8. Product owners need to be given assistance in effectively complementing the marketing strategy of the MDRF. Training sessions can be scheduled for product owners.

9. Training of staff on knowledge of attractions along the route, needs to be regular and coordinated.

10. The MDRF needs to create links and networks with both public and private businesses in the area. This will lead to better cooperation between 
stakeholders which, in turn, can result in better services provided to tourists (which corresponds with the views of Lourens, 2007:89).

11. The inputs from the Free State Tourism Authority need to be secured.

12. The MDRF needs to engage with authorities on maintaining road and other infrastructure, such as better signage (which correlates with the views of Lourens, 2007:89).

13. MDTRF must engage with local tourism forums to improve and coordinate tourism marketing strategies.

\section{Lessons from Namibia}

Tourism routes and LED can be used as a development tool for marginal or rural areas, because they have the potential to stimulate economic activity and bring tourists into these areas. Therefore, it is important to include local communities in the decisionmaking process, considering the type and scale of tourism development and making sure that they benefit from tourism. The commitment to local small business development should be central to any tourism route planning that is linked to LED objectives.

In Namibia it was necessary to ascertain the perceptions of product owners and LED officers regarding LED and tourism on the Four Deserts Tourism Route. It is insightful that all respondents (100\%) agreed route tourism have the potential to aid LED. The majority of the feedback received also showed that the communication network between product owners and the LED offices in the respective research area were very poor. Communication between public and private sector is an important aspect in LED and route tourism as the public sector needs to be informed about new products and developments in their area of operation. On the other hand, private sector need to know what public sector is doing regarding relevant marketing and tourism development. Meyer (2004) reiterates that if communication and cooperation between public and private sector is sufficient in order to grow a route, travelling along a route should be a pleasurable experience.

The heightened interest in community and pro-poor activities in rural LED strategies has meant that route tourism as a form of LED has become increasingly important. This is due to the potential of rapidly optimising the synergies between job creation, tourism and conservation (Open Africa, 2002:4). In some parts of the world, the concept of rural trails, heritage routes or scenic roads is used extensively, particularly in the context of promoting rural tourism (Olsen, 2003; Denstadli \& Jacobsen, 2011).

In order to for the Four Deserts Tourism Route to operate as a fully functional route in order to aid LED and tourism development, the following recommendations were made:

1. A management team must be appointed to further develop, manage and market the Four Deserts Tourism Route in order to aid LED and tourism development. 
2. Shorter sub routes can also be better developed and promoted as attractions to that town or area.

3. Route development can be expanded to offer a route that links with South Africa - such as the Cape to Namibia route.

4. Clear and proper signage and rest stops, and look out points must be provided along the Four Deserts Tourism Route.

5. The safety of tourist travelling the Four Deserts Tourism Route must be secured, by regular road maintenance and patrolling of remote areas.

6. LED needs to be promoted by involving the local community in business opportunities and promote their culture.

7. Local tourist guides should be better trained and their knowledge should be continuously updated.

8. Areas such as national parks, public toilets and rest areas should be better maintained and kept clean.

9. Networks with public and private businesses in the area must be created, to establish better co-operation between stakeholders on a continuous basis.

10. Government buy-in and support for the route needs to be paramount.

11. Because the Four Deserts tourism route can aid LED in the area, local communities must be assisted by the government to develop themselves with self-sustaining projects that will develop their local cultures and traditions.

12. Creating a data base of tourism product owners will also assist both public and private sector with tourism development and marketing

Stakeholders should thus work together and compete with other areas, and not with one another. This will enable product owners to collectively target accessible markets. It is also important that the managers and LED officials of the Four Deserts Tourism Route must think long-term and bigger than just the route itself, because the route must link in with the macro level strategic plan for Namibia.

\section{Conclusion}

Destinations want to attract tourists and therefore needs a portfolio of well managed tourism products, management and development. Furthermore, attractions need sufficient funding and good stakeholder relationships in order to thrive as tourist destinations. LED thus plays an important role in tourism growth in particular in less developed rural tourism areas. Well-developed LED policies, the implementation thereof and stakeholder buy-in and involvement, are important for tourism growth as it can provide the road map for tourism development.

From the research it can be concluded that a number of LED imperatives can be identified from both case studies which are necessary for LED and tourism growth. 


\section{These are:}

Better communication between LED officials and stakeholders; Improved marketing strategies and the implementation thereof; Improvement of tourism infrastructure; Government buy-in and support and Tourism linkages to be established with other tourism products.

It is clear that the attributes mentioned above can lead to LED adding to the development and growth of tourism in the respective areas. Based on the findings of the study, this section presents suggested activities to be considered in creating environments for the utilization of tourism to grow LED in both geographical areas.

\section{References}

Aaker, D., Kumar, V. \& Day, G. 2007. Marketing research. $9^{\text {th }}$ ed. New York. John Wiley \& Sons.

Akama J. S. \& Kietie, D. 2007. Tourism and socio-economic development in developing countries: A case study of Mombasa Resort in Kenya. Journal of Sustainable Tourism, 15(6):735-748.

Bunghez, L.C. 2016. The Importance of tourism to a destination's economy. Journal of Eastern Europe Research in Business \& Economics. IBIMA Publishing,(1):1-9.

Carroll, S. 2015.Types of research design you can use for your dissertation. Available from: http://www.dissertation-statistics.com/research-design.html. Date of access: 7 October 2017.

Christie, I., Fernandez, E., Messerli, H., \& Ward, L. 2013. Tourism in Africa: harnessing tourism for growth and improved livelihoods. Africa Development Forum, World Bank publication.

Cooper, D \& Schindler, P. 2006. Business research methods. $9^{\text {th }}$ ed. Harlow: Prentice Hall.

DEAT. 1996. Department of Environmental Affairs and Tourism. National White Paper on the Development and Promotion of Tourism. Pretoria. Government Printer.

DEAT. 1998. Department of Environmental Affairs and Tourism. The White Paper on Local Government. Pretoria. Government Printer.

Denstadli, J., \& Jacobsen, J. 2011. The long and winding roads: Perceived quality of scenic tourism routes. Institute of transport economics. Oslo, Norway 32, $780 \quad 790$ [online]. Available from http://www.elsevier.com/locate/tourman.

Date of access: 10-March 2018.

Domestic Tourism Growth Strategy. 2012. The Domestic Tourism Growth Strategy

2012-2020 Pretoria. Government Printers.

Elliott, R. \& Percy L. 2007. Strategic brand management. $2^{\text {nd }}$ ed. Oxford University Press, London. 
Finn, M., Elliot, M. \& Walton, M. 2000. Tourism and leisure research methods. Data Collection, Analysis, and Interpretation, $1^{\text {st }}$ ed. Essex, Longman.

George, R. 2014. Marketing Tourism in South Africa. $5^{\text {th }}$ ed. Oxford University Press, South Africa.

GTZ, 2008. Partnerships between Government and Business in South Africa: A Practical Guide, GTZ and IDC. Pretoria and Johannesburg.

Keyser, H. 2011. Developing tourism in South Africa - towards competitive destinations. $2^{\text {nd }}$ ed. Oxford University Press (Pty), Cape Town, South Africa.

Kumar, R. 2011. Research methodology: step-by-step guide for beginners. $3^{\text {rd }}$ ed. Sage publications, London.

Leedy, P. \& Ormrod, E. 2010. Practical research: planning and design. Upper Saddle River, NJ: Pearson Education.

Lourens, M. 2007. The underpinnings for successful route tourism development in South Africa. University of Witwatersrand, Master thesis in Tourism, Johannesburg.

Malhotra, N.K. \& Birks D.F. 2003. Marketing research: An Applied approach. $2^{\text {nd }}$ ed. $\quad$ Prentice hall, London.

Maps of Southern Africa 2018 [online]. Available from http://www.africaguide.com/afmap.htm. Date of access: 22 April 2018.

Maree, K. \& Pietersen, J. 2007. Surveys and the use of questionnaires. Van Schaik Publishers, South Africa.

Meyer, D. 2004. Tourism routes and gateways: key issues for the development oftourist routes and gateways and their potential for pro-poor tourism. London: Overseas Development institute.

Ministry of Environment and Tourism (MET) Namibia. 2016. Statistical report, 2016, Windhoek.

Mustafa, A. 2010. Research Methodology. $1^{\text {st }}$ ed. Krishan Nagar, Delhi. India.

National Department of Tourism: NDT 2017 Revised Draft of the National Tourism Sector Strategy 2020 NTSS.

Ncube, M., Nyarko, Y. \& Bergman, E. 2013. Africa tourism monitor. Available from: http://www.afdb.org/September2013-AfricaTourismMonitor. Date of access: 28 September 2017.

Nel, E. \& Humphrys, G. 1999. Local Economic Development: Policy and Practice in South Africa. Development Southern Africa, 16(2): 277-289.

NTSS. 2017. National Tourism Sector Strategy (NTSS) 2016-2026. [Online Available from: https://www.tourism.gov.za/AboutNDT/Publications. Date of access: 7 February 2018.

Olsen, M. 2003. Tourism themed routes: A Queensland perspective. Journal of Vacation Marketing, 9: 331-341. 
Open Africa, 2002. Information Relating to the African Dream Project. Cape Town, Online: www.openafrica.org./. Date of access: 20 March 2018.

Page, S.J. \& Connell, J. 2014. Tourism: a modern synthesis. 4th ed. Hampshire: United Kingdom.

Parasuraman, A., Grewal, D. \& Krishnan, R. 2007. Marketing research. $2^{\text {nd }}$ ed. Boston: Houghton Mifflin Company.

Reddy, P. and Wallis, M. 2012. Local Economic Development. A critique of the African experience. Politeia, 31(2), 70-88.

Report on the Namibia Tourism Exit Survey 2012-2013, 2013; Namibia Tourism Satellite account, 5th ed. n.d.

Rodriguez-Pose, A and Tijmstra, S. 2007. Local Economic Development as an alternative approach to economic development in Sub-Saharan Africa. London: World Bank.

Rogerson, C. M. 2004. Tourism and uneven local economic development: the experience of route tourism in South Africa, in C.M. Rogerson, \& G. Visser (Eds), Tourism and Development Issues in Contemporary South Africa, $\quad$ Pretoria: Africa Institute of South Africa: 399-419.

Rogerson, C. and Nel, E. 2016. Planning for local economic development in space of despair: key trends in South Africa's 'distresses areas'. Local Economy, 31(1-2): 124-141.

Rogerson, C and Visser, G. 2004. Tourism and development issues in contemporary South Africa. 1 ed. Pretoria: Africa Institute of South Africa.

SADC (Southern Africa Development Community). 2018. Southern AfricaDevelopment Community: Towards a common future [online]. Available from:http://www.sadc.int. Date of access: 24 May 2018.

Scholz, S. 2009. Tourism, nature conservation and environmental legislation in Namibia. In Saarinen, J., Becker, F., Manwa, H. \& Wilson, D. (eds.) Sustainable tourism in Southern Africa. Local communities and natural resources in transition, 150-168. Channel View Publications, Bristol.

South Africa Tourism (SAT). 2018. Your guide to South Africa [online]. Available from: https://www.southafrica.net. Date of access: 24 May 2018.

South African Tourism Planning Toolkit for local government [online]. Available from:

https://www.tourism.gov.za/AboutNDT/Branches1/Knowledge/Documents/SA20Tourism\%20Planning\% 20Toolkit\%20FINAL.pdf. Date of access: 25 May 2018.

Spenceley, A. \& Meyer, D. 2012. Tourism and Poverty Reduction: theory and practice in less economically developed countries. Journal of Sustainable Tourism, 20

Struwig, F. \& Stead, G. 2007. Planning, designing and reporting research. Cape Town: Pearson Education, South Africa.

Swarbrooke, J. 1999. Sustainable tourism management. New York: Cabi publications.

Turpie, J., Lange, G., Martin, R., Davies, R. \& Barnes, J. 2004. Strengthening Namibia's system of national protected area. Subproject 1: Economic analysis and feasibility study for financing. Ministry of Environment and Tourism, Windhoek. 
World Bank 2017. What is local economic development [online]. Available from http://go.worldbank.org/EA784ZB3F0. Date of access 25 April 2018.

World Bank 2018. International tourism number of arrivals [online].

https://data.worldbank.org/indicator/ST.INT.ARVL. Date of access 25 April 2018.

WTTC (World Travel \& Tourism Council). 2018. World Travel and Tourism Council [online]. Available from https://www.wttc.org/. Date of access 25 April 2018.

Xasa, T. 2016. Executive Development Programme for black women tourism managers. [Online] Available from: https://www.tourism.gov.za/AboutNDT/Ministry/News/Pages. Accessed 08 February 2018.

ZIGMUND, W. 2003. Essentials of marketing research. $2^{\text {nd }}$ ed. Thomson Learning, $\quad$ Ohio. 